\title{
Contribution to the histology of Biompbalaria glabrata
}

\author{
Contribuição à histologia da Biomphalaria glabrata
}

Queli Teixeira Lemos

\begin{abstract}
A combination of histological techniques applied to the study of Biomphalaria glabrata yielded some interesting new data about the histology of this snail, a major intermediate host of Schistosoma mansoni in Brazil. Three kinds of pigments were identified: a dark pigment which bleached following oxidation with potassium permanganate; a lipofuchsinlike, diastase-resistant PAS-positive pigment and an iron-containing pigment, probably related to hemosiderin. Calcium was detected in small deposits within the connective tissue and forming a dense core inside the chitinous radular teeth. The presence of fibrils, staining with sirius-red and birefringence under polarized light strongly suggest primitive collagen tissue. The radular apparatus appeared as a storing site for glycogen, while abundant Alcian-blue positive material (proteoglycans) was extremely concentrated in the radular sac.
\end{abstract}

Key-words: Biomphalaria glabrata. Histology. Pigments

Resumo Uma combinação de várias técnicas histológicas permitiu alguns achados de interesse para a histologia da Biomphalaria glabrata, principal hospedeiro intermediário do Schistosoma mansoni no Brasil. Três tipos de pigmentos foram identificados: um pigmento escuro, que se descora após oxidação pelo permanganato de potássio; outro que é semelhante à lipofuscina, que se cora pelo PAS e é diastase- resistente, e um pigmento que contém ferro, provalvelmente, relacionado com a hemossiderina. O cálcio foi identificado em pequenos depósitos no interior do tecido conjuntivo e formando pequenos núcleos no interior dos dentes quitinosos da rádula. A presença de fibrilas coradas pelo sírius-vermelho, exibindo birrefrigência sob luz polarizada, sugere fortemente a presença de um tecido colágeno primitivo. O aparelho radular foi visto como um local de armazenamento do glicogênio, enquanto a presença de abundante material amorfo positivo para o azul de alciano (proteoglicano) apareceu em grande concentração no saco radular.

Palavras-chaves: Biomphalaria glabrata. Histologia. Pigmentos.

The histology of Biomphalaria glabrata is now well known. Besides the classical study of Pan' 9 there are several others 34710 , concerning not only the optical microscopic appearance, but also ultrastructural and histochemical features. However, there remain some controversies about the true nature of the extracellular matrix, especially whether true collagen fibers are present in it. Also, there are some other aspects which seem little explored, such as those related to the nature and significance of pigments present in snails and the composition and histophysiology of the glandular and radular apparatus.

As an important step toward a program for a large study of experimental schistosomiasis, the need for a better understanding of $B$. glabrata histology was felt. In the present investigation normal, adult, laboratory raised specimens of $B$.

Laboratório de Patologia Experimental, Centro de Pesquisas Gonçalo Moniz / FIOCRUZ. Rua Valdemar Falcão/ 121, 40925-001 Salvador, BA, Brasil.

Address to: Drª Queli Teixeira Lemos. Centro de Pesquisas Gonçalo Moniz (FIOCRUZ). Rua Valdemar Falcão 121, Brotas, 40295-001 Salvador, BA, Brasil, Tel: 5571 356-8787, Fax: 5571 356-4292.

Recebido para publicação em 3/4/98. 
glabrata were microscopically examined with the help of a battery of staining methods to attempt a contribution on some obscure and controversial issues.

\section{MATERIAL AND METHODS}

Adult $B$. glabrata from Feira de Santana, Bahia, Brazil, raised from eggs within aquarium at the Gonçalo Moniz Research Center (Fiocruz) Salvador, Bahia, Brazil and measuring approximately $12 \mathrm{~mm}$ diameter, were anesthetized with menthol crystals in water during 40 minutes. After the shell was carefully broken, the soft parts of the mollusk were removed and immediately fixed either in Bouin's fluid added of acetic acid or in phosphate buffered $10 \%$ formalin. Fixation in Bouin lasted for six hours, the tissues being conserved in $70 \%$ alcohol thereafter. After paraffin embedding, the $5 \mu \mathrm{m}$ sections obtained were submitted to the following staining techniques: hematoxilyn and eosin, Masson's trichrome, Movat's pentachrome stain, periodic acid Schiff (PAS) either with and without previous diastase treatment, alcian blue, orcein for elastic fibers, Gomori's reticulum impregnation, Mayer's mucicarmin for mucin (with mouse intestinal mucosa as control), Van Kossa for calcium, Perls for iron, Woelckes for myelin and potassium permanganate for tissue breaching. Techniques were performed according to the instructions on the AFIP Manual12. Slides were also stained with the picro-sirius-red method, according to Junqueira et al5, and microscopically examined with or without polarized light.

\section{RESULTS}

The diverse staining methods utilized allowed for a good general review of the histology of $B$. glabrata. However, the present results concern only those aspects on which possible addition to present knowledge is presumed.

Pigments. Three types of pigments appeared prominent in the sections examined: a) a dark brown or black pigment was abundant along the basal portion of the superficial epithelial lining

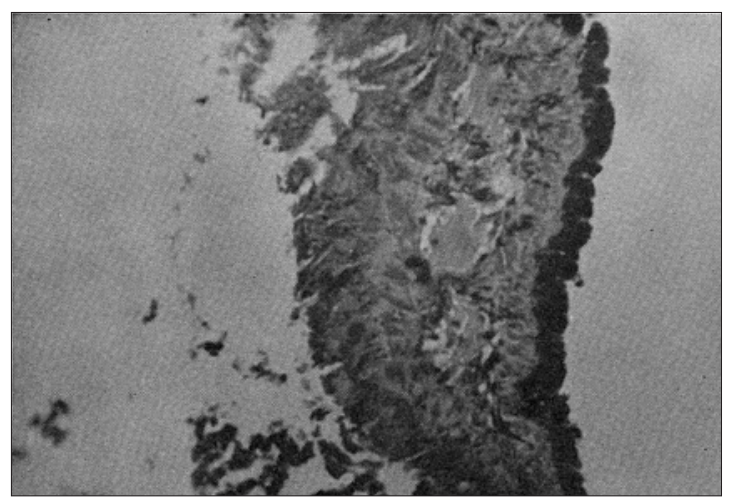

Figure 1 - A large amount of a dark, melanin-like pigment is accumulated along the superficial epithelium of the mantle collar. Hematoxylin \& eosin, 120x.

type of pigment presented with a brownish hue and was iron-positive. It was the most abundant of the pigments found in the sections. A relatively which cover the entire molluscan body. This pigment completely disappeared after treatment of the section with potassium permanganate (Figures 1 and 2); b) a yellowish granular pigment found in different tissues, but mainly in the connective tissue of the mantle collar, both extra and intracellularly. This pigment was PAS positive, diastase resistant and did not bleach following potassium permanganate treatment. The third

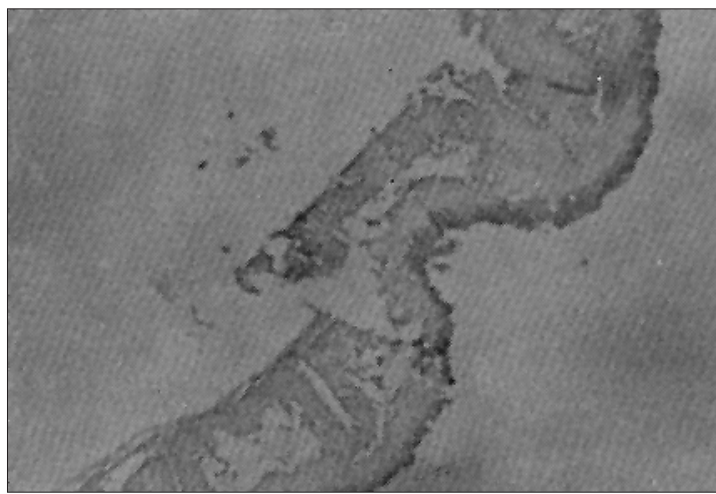

Figure 2 - The same section of Figure 1 appears colorless following treatment with $3 \%$ potassium permanganate. Hematoxylin \& eosin, 120x.

abundant amount was seen within the tubular portion of the kidney and in the digestive glands (Figure 3). The ovotestis contained a large amount, 
especially within the ovule and spermatozoid heads. Iron-positive pigment was also present at the basal layer of the external epithelial covering, in focal areas, together with the dark melaninlike pigment above described.

Radular apparatus. The radular apparatus is composed of different structures, therefore presenting a complex histology. It includes the radular sac, the radula carrier, the radula itself and the protractor and retractor muscles. The radula

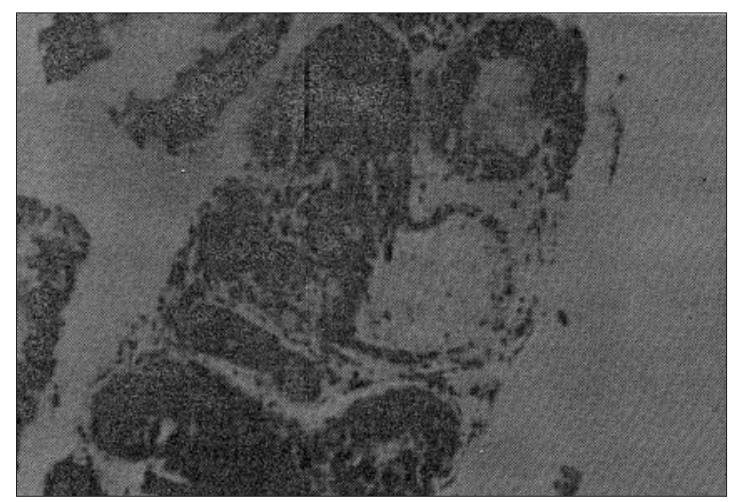

Figure 3 - Abundant iron-containing pigment is present in the interior of digestive glands. Perl's method for iron. $160 x$.

positive material is rather scanty. The radula is represented by a thick basement membrane on which a thick chitinous layer is implanted (Figure 5). This layer has a saw-like structure

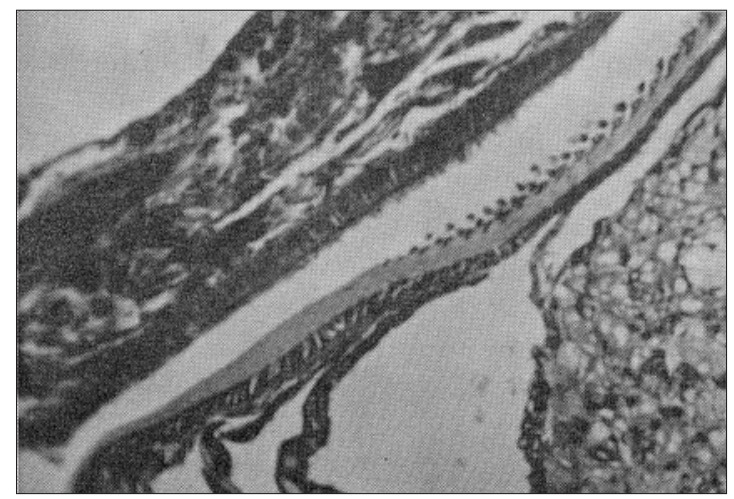

Figure 5 - A deeply blue, thick and uniform basement membrane support the little teeth of the radular apparatus. Masson 's trichrome stain, 100x. carrier is formed by large, plump, vesicular cells with well defined external membrane, arranged side by side, sometimes interposed by smooth muscle cells. The latter is well visualized when stained in red by the Movat' s pentachromic method. The plump cells contain a large amount of glycogen (PAS positive, diastase removable) (Figure 4). The radular sac, where the radula takes origin, is actually a proteoglycan-rich structure, strongly alcian-blue positive. Its content of PAS-

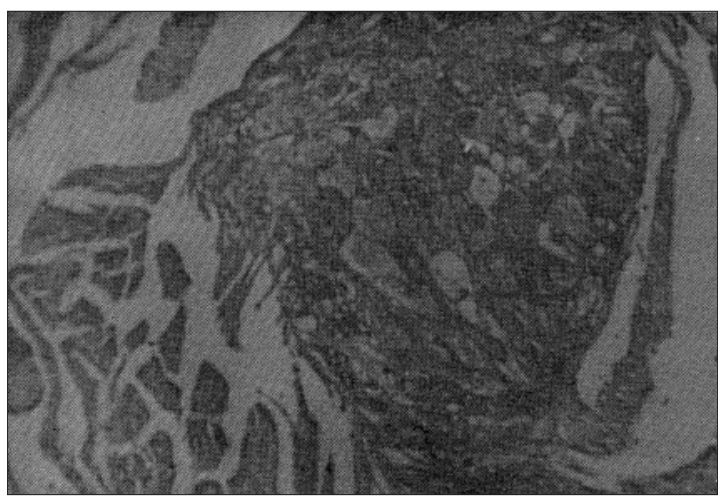

Figure 4 - Large plump cells forming the bulk of the radular carrier are strongly stained in red (PAS-positive material). Periodic acid Schiff 's method, 160x.

representative of teeth, in the center of each of them a condensed calcium-containing material is seen (Figure 6).

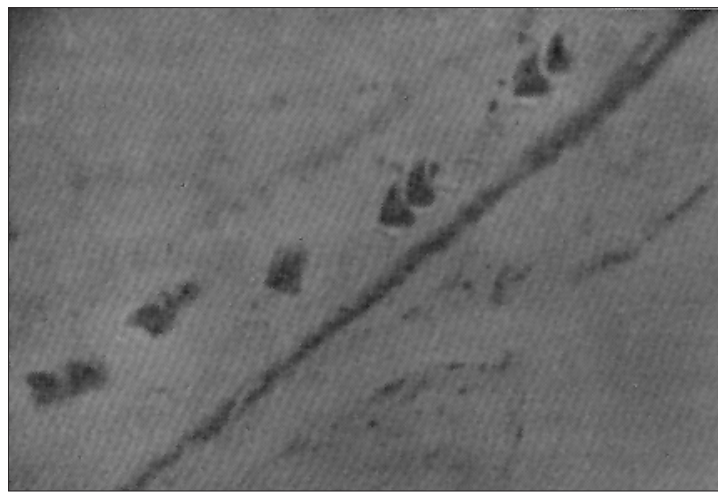

Figure 6 - The dark dots in the middle of the chitinous radular teeth represent a dense calcium-containing core. Van Kossa 's method, 100x. 
Digestive glands. These structures were remarkable for the presence of numerous secretory granules located within the high cubic and cylindrical epithelial cells making the tubular glands. The granules were more often located at the superior pole of the cells, varied in size and amount for a same gland and much more so in different individuals (Figure 7). They were PASpositive and diastase resistant, strongly alcian blue-positive, but did not stain for mucin. Diffuse and focal PAS-staining, resistant to diastase digestion, was also observed in the cytoplasm of epithelial cells throughout the molluscan tissues, especially in the nidamental and albumen glands.

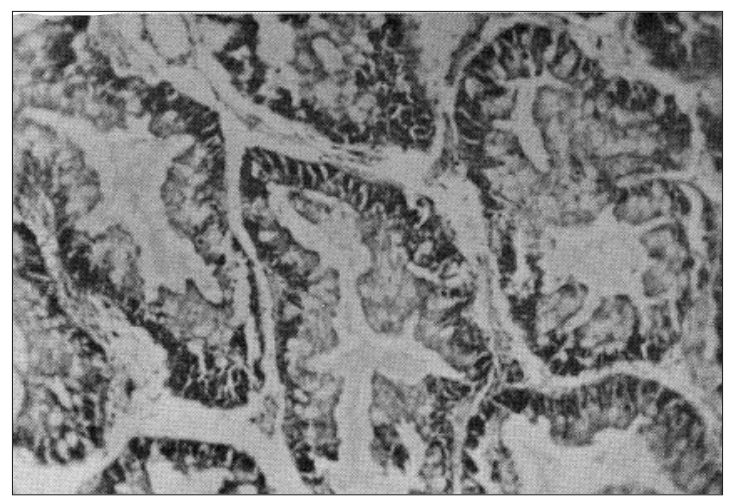

Figura 7 - Numerous blue-stained secretory granules appear in the epithelial part of digestive gland. Masson' $s$ trichrome strain, 160x.
Extracellular matrix fibers. In areas with abundant connective tissue, such as the foot region, the mantle collar, esophagus and periesophageal region, numerous thin and long fibers were seen forming sometimes a cris-crossing pattern. Others fibers had a wavy appearance (some of them stained as elastic fibers by orcein), while others were thick, with variable degree of thickness and oriented in several directions. These thin and thick fibers took a strong red staining with sirius-red and appeared birefringent and with striated periodicity under polarizing light (Figure 8). The color hue varied from red to yellowish. Sometimes, especially at the foot region, fine fibrils forming an argirophilic network were also observed.

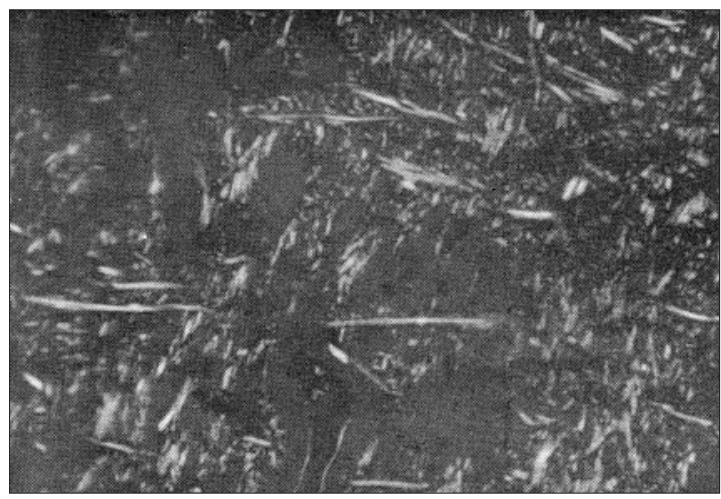

Figure 8 - Straight and wave refringent fibers and fibrils are abundant in this section taken from the foot region of the snail. Picro-sirius red method with polarized light, 120x.

\section{DISCUSSION}

The results presented above were selected as the most representative obtained in the present study. There is some reluctance to identify or even compare findings in invertebrate histology with those of superior animals. That attitude is of course correct, since differences do exist between them. However, from a practical point of view it is interesting to stress similarities rather than differences. For instance, the pigments found in B. glabrata are morphologically and chemically very similar to the main pigments found in vertebrates, including man. The so-called melaninlike pigment so abundant in $B$. glabrata, behaves as their human counterpart, undergoing complete bleaching after being peroxidized by potassium permanganate. The two other pigments are similar to lipofuscin and hemosiderin, respectively. There is an iron-containing pigment present in hemolymph 128 . In the tissues the iron-containing pigment may represent iron storage. On the other hand, Its prominent presence in the tubular portion of the kidney may be related to excretion of excess pigment. it is also abundant in the ovo-testis and related structures 11 .

The radula carrier appears as an important site of storage for glycogen, while the radicular sac is rich in proteoglycan, which is in keeping with its function as both cushion and support for the radula. The suggestion that the serrilhated part of the radula represents primitive teeth is supported by the present demonstration of a calcium nucleus within each one of them. 
The findings showing variation in size, density and number of PAS-positive diastase-resistant granules in the glandular epithelium seen in different parts of the same gland and, better still, in glands from different specimens indicate that the activity in these glands pass through functioning cycles and is far from uniform. Probably there occur waves of functional activity along the glandular epithelial line. The exact nature of the granules has not been determined, but present findings are consistent with the presence of a complex glycoprotein content. However no evidence of mucin could be demonstrated, nor the presence of caliciform cells.

Fibers with staining characteristics of collagen have been demonstrated in several locations, usually accompanied by a few orcein-positive elastic fibers and an occasional net of argirophilic reticular fibrils. The observation of refringent fibers when sirius-red stained sections are viewed under polarizing light is considered to be diagnostic of collagen fibers 56 . This is important to register because the encapsulating or granulomatous lesions seen around disintegrating $S$. mansoni sporocysts usually present concentric collagenlike fibers that do not take the sirius-red staining and show no refringence 13 . After seen such lesions on optical microscope preparations one may doubt whether true collagen fibers are formed in B. glabrata at all. Actually these fibers around the encapsulating lesions (granulomas) are formed by cytoplasm prolongation from numerous amebocytes, as can be seen under the electron

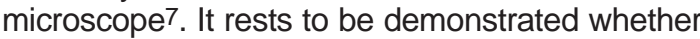
stromal reaction in $B$. glabrata is characterized by the production of fibrosis, with neoformation of collagen fibers. The behavior of the extracellular matrix in B. glabrata is indeed a point of considerable interest in comparative pathology and needs further study.

\section{ACKNOWLEDGEMENT}

Thanks are due to Dr. Zilton A. Andrade for orientation and support.

\section{REFERENCES}

1. Cheng TC, Foley DA. Hemolymph cells of the bivalve mollusc Mercenaria mercenaria: an electron microscopical study. Journal Invertebrados Pathology 26:341-351, 1975.

2. Couch L, Hertel LA, Loker ES. Humoral response of the snail Biomphalaria glabrata to trematode infection: observations on a circulating hemagglutinin. Journal Experimetal Zoology 255:340-349, 1990.

3. Jeong $\mathrm{KH}$, Lie KJ, Heyneman D. The ultrastructure of the amebcyte-producing organ in Biomphalaria glabrata. Development Comparative immunology 7:217-228, 1983.

4. Jeong KH, Lie KJ, Heyneman D. An ultrastructural study on ventricular encapsulation reactions in Biomplalaria glabrata exposed to irradiated Echinostome parasites. International Journal Parasitology 4:127-133, 1984.

5. Junqueira LC, Bignolas G, Bretani RR. Picrosirius staining for collagen detection in tissue sections. Histochemical Journal 11:447-455, 1979.

6. Junqueira LC, Montes GS, Sanchez EM. The influence of tissue thickness on the Study of Collagen by the Picrosirius-polarization Method. Histochemistry 74:153156, 1982.

7. Loker ES, Bayne CJ, Buckley PM, Kruse KT. Ultrastrutcure of encapsulation of Schistosoma mansoni mother sporocysts by hemocytes of juveniles of the 10-
R2 strain of Biomphalaria glabrata. Jounal Parasitology 68:84-94, 1982.

8. Mandal C, Biswas M, Nagpurkar A, Mookerjea J. Isolation of a phosphoryl choline-binding protein from the hemolymph of the snail, Achatina fulica. Development Comparative Immunology 15:227-239, 1991.

9. Pan, Chia-Tung. The general histology and topographic microanatomy of Australorbis glabratus. Bulletin Museum of Comparative Zoology 119:237-259, 1958.

10. Pan, Chia-Tung. Some biochemical and immunological aspects of host-parasite relationships: Generalized and focal tissue responses in the snail Australorbis glabratus, infected with Schistosoma mansoni. Annals New York Academy Science 113:475-485, 1963.

11. Paraense WL. The sites of cross and self-fertilization in planorbid snails. Revista Brasileira de Biologia. 36:535539, 1976.

12. Prophet EB, Mills B, Arrington JB, Sobin LH. Laboratory Methods in Histotechnology. Armed Forces Institute of Pathology, Washington. 1992.

13. Souza CP, Cunha RC, Andrade ZA. Development of Schistosoma mansoni in Biomphalaria tenagophila, Biomphalaria straminea and Biomphalaria glabrata. Revista do Instituto de Medicina Tropical de São Paulo 37:201-206, 1995. 